\title{
International movements, post-apartheid dispensations and illegal immigration into South Africa
}

\author{
KWOTELA' AND CLETSIRI ${ }^{2}$
}

\begin{abstract}
Arising from the supposed negative impact of illegal immigration, including security threats as well as recent xenophobic violence, the South African Government would like to counter illegal immigration. To do this, it needs to understand the root causes of illegal immigration into the country. This article, therefore, seeks to explain and interpret why illegal immigrants make South Africa their ideal choice of destination. To provide a context, the article begins with a discussion on the research setting, that is, the South African international boundaries. Thereafter, the article discusses the concept of illegal immigration from the South African context before reviewing literature on the number of illegal immigrants in South Africa and the supposed impact. The article then explores literature on international movements and discusses established migration frameworks that explain and interpret these movements. Lastly, to confirm some facts arising from the review, we interviewed officials that manage illegal immigration as well as detained immigrants. We establish that four migration streams that have created a blended society in Southern Africa sparked illegal immigration into South Africa. The article conclude that the problem of illegal immigration into South Africa is perpetuated by deep-rooted migration networks. Therefore, if the South African Government wants to avert illegal immigration, its policy-makers should examine these roots and take them into account to arrive at a solution that is in sync with the root causes of the problem.
\end{abstract}

Keywords: immigration, illegal immigrants, migration push and pull factors, migration networks

\section{South African's international boundaries}

As Figure 1 shows, the current official boundary of South Africa stretches from the Atlantic Ocean on its west to the Indian Ocean on its east. To its South are the two Oceans while to its north is Namibia, Botswana, Zimbabwe, Mozambique, and Swaziland to its east. There is also Lesotho right within its boundaries. As detailed in Thompson (1960), Walker (1962) and Beck (2014), this boundary was established in 1910 after combining two Boer independent countries - The South African Republic (formerly the Transvaal Colony) and

1 Wits Graduate School of Governance (WSG), University of the Witwatersrand, P.O. Box 601, Wits, 2050, South Africa, E-mail: kambidima.wotela@gmail.com

2 Wits Graduate School of Governance (WSG), University of the Witwatersrand, P.O. Box 601, Wits, 2050, South Africa, E-mail: cleophas.letsiri@gmail.com

Td The Journal for Transdisciplinary Research in Southern Africa, 11(4), December 2015, Special edition,

pp. 99-117. 
the Orange Free State (formerly the Orange River Colony) - and the two British colonies, that is, the Cape Colony and the Natal Colony. Obviously, the previous four international boundaries that make-up the current South Africa are a product of the Berlin Conference of 1884 to 1885 that decided on international boundaries of the African continent. ${ }^{3}$ However, we do not engage this debate because our focus is illegal immigration vis-à-vis the current official boundary of South Africa.

Figure 1: The map of South Africa showing its neighbouring countries

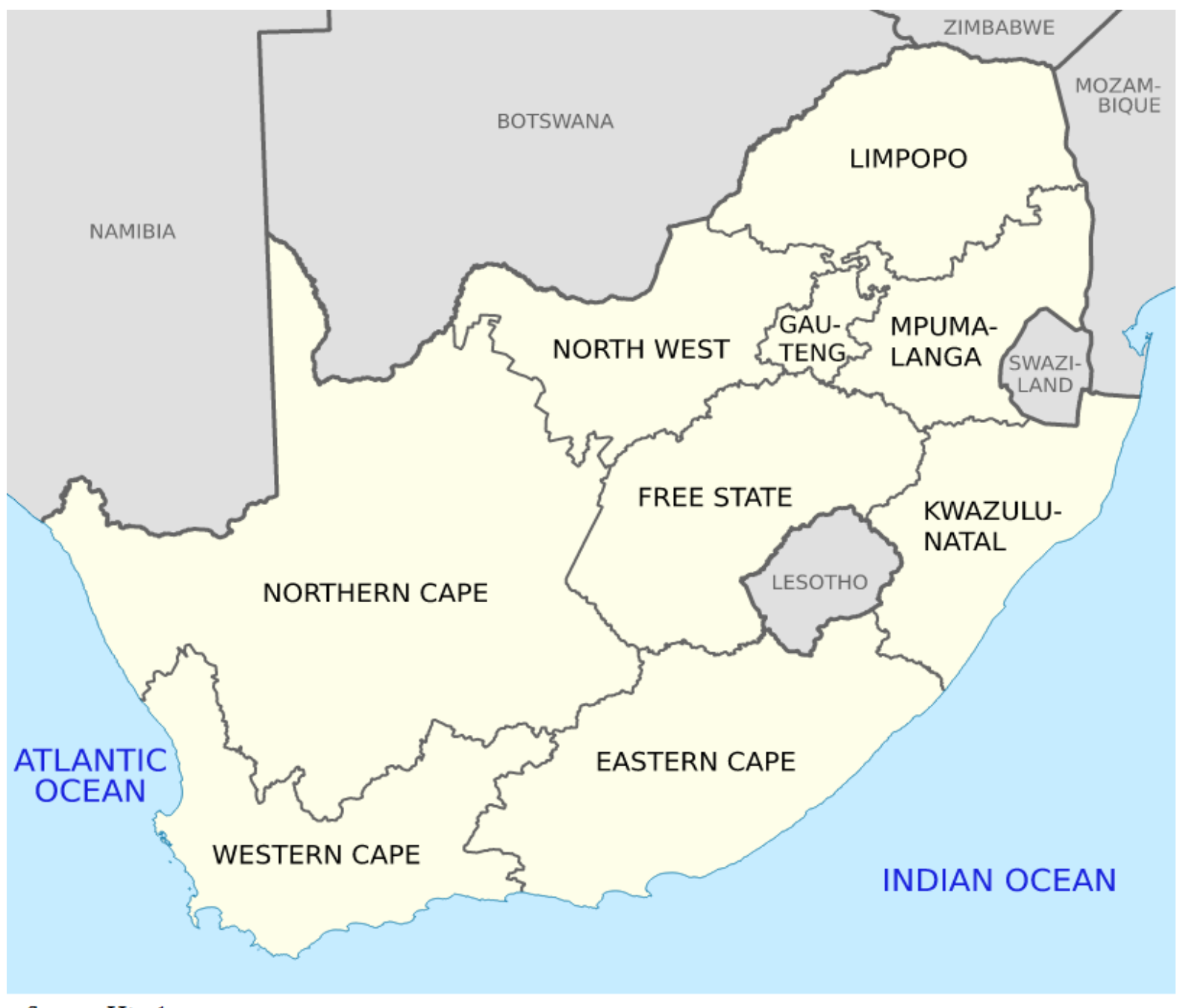

Source: Htonl

\section{Concept of illegal immigration}

As Figure 2 conceptualised by the authors shows, migration ${ }^{4}$ - temporal, seasonal, and permanent movement of people from one society to another - is one of the three

3 At the request of Portugal, German Chancellor Otto von Bismark called major western powers to realign their control of Africa. The outcome of this conference was current artificial international boundaries that cut across communities and ethnic societies because they used land marks such as rivers and mountains for this purpose.

$4 \quad$ Statistics South Africa (2004: 27) describe "migration as the movement into and out of countries, and within countries, from non-urban to urban areas or the other way around, or from one province or state to another". 
components of demography, the other two being fertility and mortality. Migration can occur several times in an individual's life - unlike the other two components, that is, an individual is born once and dies once. Further, migration comprises of internal and international migration. Internal migration describes within country migration or the movement of people across subnational boundaries - for example, when individuals belonging to one municipality or province move to another municipality or province. International migration ${ }^{5}$ describes the movement of individuals across international boundaries-for example, when South Africans move to other countries (emigration) or non-South Africans move into South Africa (immigration). ${ }^{6}$ Gebrewold (2007) has distinguished immigrants into two groupsthat is, individuals that move into a country involuntarily or on humanitarian grounds and those that move voluntarily. The former include those seeking asylum and refugees. The latter do so to set up businesses, to work, or to unite with family.

Figure 2: The three components and subcomponents of demography with migration, international migration, immigration status

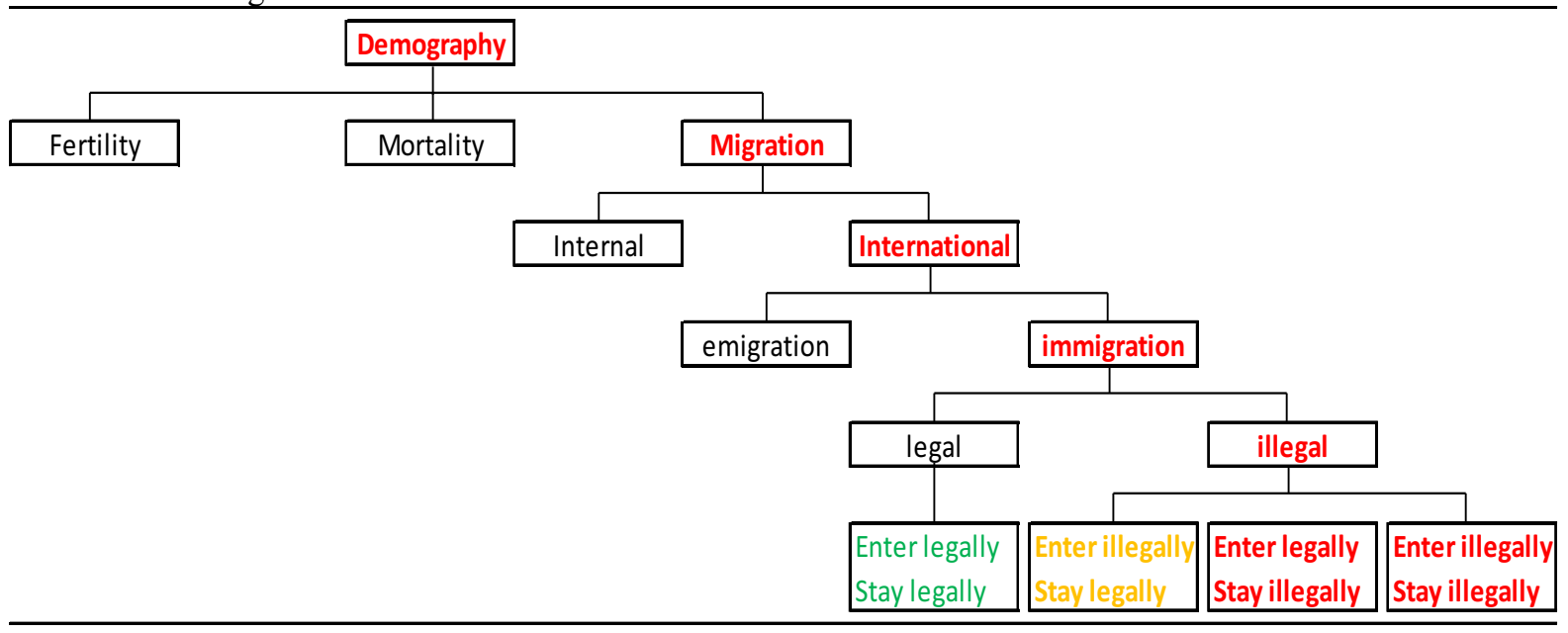

Further, one can divide individuals coming into a country into legal immigrants and illegal immigrants. The former obtain official permission to enter and stay for a prescribed duration in the country of destination. The South African Immigration Act 4437 (2002) accommodates within its boundaries non-South Africans with temporary or permanent residence permits to visit, study, work, and transact. The illegal immigrants comprise individuals without legitimate or valid official permission to be in South Africa. Lebhart (2002), Crush \& Williams (2005), as well as Campbell (2007) break down illegal immigrants into two groups - that is, those that enter South Africa legally but stay on after their permits have expired and hence remain in the country illegally as well as those that enter South Africa illegally and go on to stay illegally. To this, we can add one more group, that is, those that

5 "International migration ... as we know it [today] came into being around the beginning of the twentieth century" (Zolberg, 2006: 223).

6 For internal migration, outmigration (rather than emigration) refers to persons moving from a particular region while in-migration (rather than immigration) refers to persons moving into a particular region. Solomon (2003) has described the different typologies of migration within the context of Southern Africa in general and South Africa in particular.

7 Klotz (2012) has discussed the coming of this Act as well as its limitations especially its focus on enforcement. 
enter illegally but legalise their stay in South Africa. Due to the supposed negative impact of illegal immigration including security, the South African Government would like to counter illegal immigration. Therefore, our focus is on foreign nationals that are in South Africa illegally regardless of their status when they entered the country. ${ }^{8}$

The South African Government applies national, continental, and global procedures and protocols to deal with immigration. National documentation includes the 1996 Constitution of the Republic of South Africa, the South African Refugees Act 130 of 1998, and the South African Immigration Act 443 of 2002. At continental level, it is the 1969 African Union convention governing the specific aspects of refugee problems in Africa. ${ }^{9}$ The global documentation includes the 1948 United Nations Universal Declaration of Human Rights; ${ }^{10}$ and, the 1951 and 1967 United Nations Convention and Protocol Relating to the Status of Refugees ${ }^{11}$. Kabwe-Segatti (2008) has detailed these procedures and protocols. Needless to say, refugees in South Africa are not restricted to designated camps and are free to go anywhere and participate in economic and social ventures. This makes illegal immigration easy and difficult to counter. In the next section, the article reviews literature on the number of illegal immigrants in South Africa and thereafter the supposed impact of the problem. The article then explores literature on international movements that sparked illegal immigration into the country and established migration frameworks that explain and interpret these movements. Lastly, we interviewed officials that manage illegal immigration to confirm some facts arising from the review.

\section{Illegal immigrants in South Africa}

The Department of Home Affairs can account for legal immigrants as well as those that enter South Africa legally but stay on illegally after their permits have expired. However, they cannot account for individuals that enter the country illegally and stay illegally. ${ }^{12}$ As a result, the South African Government does not know how many illegal immigrants are in South Africa. ${ }^{13}$ For example, Crush and Williams (2005: 12) have observed that "the political and economic conditions in Zimbabwe have caused an increase in economic migration to neighbouring countries such as South Africa and Botswana, however the often cited numbers of 2-3 million [illegal Zimbabwean immigrants] in South Africa ...” is an upward exaggeration. Similarly, Polzer (2010) has also argued that the commonly quoted estimates, ranging from one to eight million immigrants in South Africa, are based on unreliable

In this article, we do not refer to immigrants staying in South Africa illegally including those accorded asylum or refugee status by the South African Government, limitation that we take on for purposes of being focused.

http://www.au.int/en/sites/default/files/Convention_En_Refugee_Problems_in_Africa_AddisAbaba_ 10September1969_0.pdf

http://www.un.org/en/documents/udhr/

http://www.unhcr.org/3b66c2aa10.html

12 Peter Mudau of the South African Police Service has stated that authorities know that there are undocumented foreign nationals who enter South Africa illegally through the fence at the South Africa/Zimbabwe border (e-News Channel Africa, 2013). 
statistics. Instead, she proposes that there are about 2 million immigrants in South Africa that is about 4 per cent of the South African population.

Table 1 presents provincial residence by citizenship figures in the Statistics South Africa 2011 Census report even though they did not ask about citizenship per se (Statistics South Africa, 2012) ${ }^{14}$ Approximately 2 million (1 $621691+373$ 218) immigrants live in South Africa ${ }^{15}$ a figure equal to Polzer's (2010) estimate. As Kok \& Collinson (2006) have also established, the majority of foreign nationals in South Africa reside in Gauteng Province - the economic power house of South Africa. Of this group, the "unspecified" figure (373 218) probably captures some, but definitely not all, illegal immigrants living in South Africa.

Table 1: Number of usual residents by citizenship according to province, 2011

Population Census

\begin{tabular}{|c|c|c|c|c|c|c|c|}
\hline \multirow[t]{2}{*}{ Province of usual residence } & \multicolumn{2}{|c|}{ Citizens } & \multicolumn{2}{|c|}{ Non-Citizens } & \multicolumn{2}{|c|}{ Unspecified } & \multirow{2}{*}{$\begin{array}{c}\text { Total } \\
\text { residents }\end{array}$} \\
\hline & Per cent & Number & Per cent & Number & Per cent & Number & \\
\hline Eastern Cape & 98.4 & 6334585 & 0.9 & 57938 & 0.7 & 45063 & 6437586 \\
\hline Free State & 97.8 & 2604492 & 1.9 & 50599 & 0.3 & 7989 & 2663080 \\
\hline Gauteng & 91.9 & 10984248 & 7.1 & 848620 & 1.0 & 119524 & 11952392 \\
\hline KwaZulu_Natal & 98.1 & 9921812 & 1.1 & 111254 & 0.8 & 80912 & 10113978 \\
\hline Limpopo & 96.9 & 5157148 & 2.6 & 138375 & 0.5 & 26611 & 5322134 \\
\hline Mpumalanga & 96.8 & 3856096 & 2.6 & 103573 & 0.6 & 23901 & 3983570 \\
\hline North West & 95.9 & 3298672 & 3.5 & 120390 & 0.6 & 20638 & 3439700 \\
\hline Northern Cape & 98.8 & 1111802 & 0.9 & 10128 & 0.3 & 3376 & 1125306 \\
\hline Western Cape & 96.0 & 5424444 & 3.2 & 180815 & 0.8 & 45204 & 5650462 \\
\hline Total & & 48693299 & & 1621691 & & 373218 & 50688208 \\
\hline \multicolumn{8}{|c|}{ Souce: Statistics South Africa (2012) } \\
\hline
\end{tabular}

To demonstration that features of illegal immigrants has probably changed over time, Table 2 shows the number of documented immigrants by population group between 1971 and 2001. ${ }^{16}$ Before 1994, the proportion of European White immigrants in South Africa was about 46 per cent but this has since halved to about 21 per cent. It is probable that this trend is also a reflection of illegal immigration as well. Before 1994, most illegal immigrants came from Europe mostly Whites (Crush \& Williams, 2005) but after 1994, most illegal immigrants are

14 Does this oversight indicate that the South African Government is not giving immigration the attention it deserves?

15 The Editor (2012) reports that Diego Iturralde, the Chief Director of Demographic Analysis at Statistics South Africa, thinks this number is not sensationally under-reported despite individuals hesitating to state where they were born under suspicion that Statistics South Africa will pass such information to the Department of Home Affairs, the South African Police Service, or the South African Revenue Service. In this newspaper article, it is not clear where he got the figure of 2.2 million immigrants. He affirms that migration is a tricky subject and Statistics South Africa cannot state that they have a firm hand on it.

16 Kabwe-Segatti (2008) has also provided similar but more detailed tables and figures on migration by race. 
Black Africans (Segatti, 2011) — with about 60 per cent coming from neighbouring countries especially Lesotho, Mozambique, Swaziland, and Zimbabwe. ${ }^{17}$

Table 2: Number of immigrants into South Africa by population group, 2001 Population

Census

\begin{tabular}{lrrrrrrrr}
\hline Population group & \multicolumn{2}{c}{$1975-1980$} & & \multicolumn{2}{c}{$1992-1996$} & & \multicolumn{2}{c}{$1996-2001$} \\
\cline { 2 - 3 } \cline { 8 - 9 } & Per cent & Number & & Per cent & Number & & Per cent & Number \\
\hline Asians & 2.9 & 63720 & & 2.9 & 125664 & & 2.7 & 150087 \\
Blacks & 40.5 & 894000 & & 67.9 & 2909948 & & 67.7 & 3754379 \\
Coloured & 10.4 & 228980 & & 7.7 & 331321 & 9.0 & 500460 \\
Whites & 46.3 & 1023420 & & 21.5 & 921514 & 20.5 & 136722 \\
Total & 100.0 & 2210120 & & 100.0 & 4288447 & 100.0 & 5541648 \\
\hline
\end{tabular}

Source: Statistics South Africa (2004)

\section{Supposed impact of illegal immigration}

There are certainly several positive impacts that accompany legal immigration-for example, Ellis (2008) as well as Johnson, Altbeker, and Bernstein (2010) point out how skilled immigrants have filled scarce-skills sectors as well as open businesses and employ South Africans. However, since our focus is on illegal immigration, we limit our discussion to the negative impacts of illegal immigration. First, illegal immigration is a threat to governance and security (Solomon, 2003; Zolberg, 2006). ${ }^{18}$ Second, since the number of illegal immigrants is unknown, it is impossible to plan $^{19}$ for service delivery ${ }^{20}$ (Landau \& Singh, 2008). Du Toit \& Others (2002) point out that effective and efficient service delivery depends on accurate knowledge of intended recipients. If figures for intended recipient are unknown, the quality of services is compromised. Undersupply of a public service leads to ineffectiveness while its oversupply leads to inefficiency (Kanyenze, 2004). This is probably — as implied by Hill (1990) and Cleland (1996) - why most countries with good information systems - for example, Scandinavian countries as well as Mauritius - can account for almost all their intended recipients and, therefore, do not have acute service delivery problems.

The perception is that illegal immigrants in South Africa compete with locals for jobs and consume public goods and services, therefore, “... frustrating state efforts to regulate health, education, and housing sectors” (Vigneswaran, 2008: 135). As Polzer (2010) has argued, the effects may be negligible at national and probably provincial level but they are quite notable at district and municipality level. ${ }^{21}$ Zolberg (2006: 244) argues that "despite changing conditions, the presence of immigrants and the prospect of further immigration will continue

The listing here is in alphabetical order and not an ordinal ranking.

For example, the illegal cigarette trade between South Africa and Zimbabwe (Rees, 2013).

Bryan (2004) has observed that demographic and socio-economic parameters-such as size as well as age and sex composition - of an entire population in a defined region at a specific time, and their changes thereof, are useful for accurate development planning, implementation, and evaluation.

There is a need for a research study to establish the proportion of service delivery problems that are due to unaccounted for individuals including illegal immigrants.

Landau and Singh (2008) as well as Isike (2012) have discussed the effects of immigration into South Africa at sub-national level in more detail. 
to stimulate xenophobic or at least exclusionary sentiments ..." Similarly, the Human Science Research Council (2008) and Klotz (2012) have attributed xenophobic or more specifically Afrophobia - that is, violence directed at non South Africans living in South Africa attacks $^{22}$ leading to destruction of property and life to the growing number of illegal immigrants jostling for limited resources and services with South Africans. They take the law in their hands because they think the South African Government is not managing illegal immigration effectively - Landau \& Singh (2008) refer to this as privatisation of violence.

The foregoing shows that despite poor data and methodological drawbacks, there are a notable number of illegal immigrants in South Africa. We also establish that these unaccounted for individuals pose negative impacts especially at subnational level. The next section discusses movements that led to this inflow and thereafter we review some frameworks that can explain these movements.

\section{International movements into South Africa and post-apartheid dispensations}

There are four migration streams that have created a blended society - and, therefore, strong migration networks that might have sparked illegal immigration into South Africa. Figure 3 illustrates three sets of immigration streams into South Africa from neighbouring countries and an emigration out of South Africa into neighbouring countries.

Figure 3: Immigration into South Africa from neighbouring countries and emigration out of South Africa into neighbouring countries

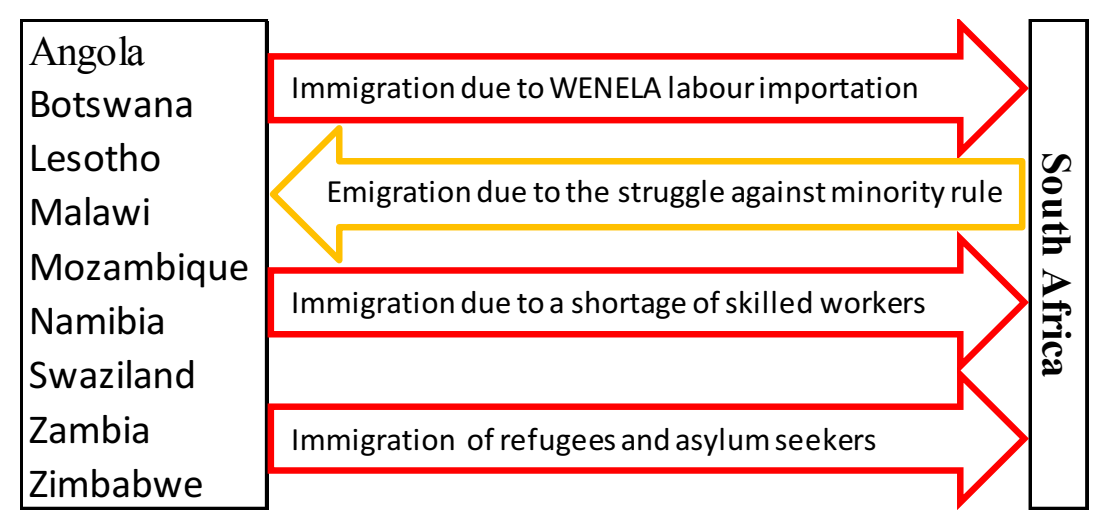

The first migration stream is forced migrant labour (Maharaj, 2004). Exceptional to the general rule where labour voluntarily drifts towards greener pastures, it is South Africa that sparked labour immigration from present-day Angola, Botswana, Lesotho, Malawi, Mozambique, Namibia, Swaziland, Zambia, and Zimbabwe (Jones, 1990). To avoid wage increases due to competition for scarce local labour and effective labour unions, the South African Chamber of Mines instituted a carefully crafted policy to recruit labour from neighbouring countries (Wilson, 1972). As a follow-up to this policy, the Transvaal Government and the Portuguese jointly created the Witwatersrand Native Labour Association (WENELA) in 1897. The WENELA centres stationed in neighbouring countries were recruitment vehicles of labour destined for South African gold mines and

22 Regardless, the South African Municipal Workers' Union (2012) think that illegal immigrants find themselves in South Africa “... to escape the ravages and poverty of their own countries", the Union does not believe that blaming and attacking foreign nationals is the answer to poor service delivery. 
farms (Kanyenze, 2004). Naturally, human beings, including Africans, find it hard to move from their comfort zones. With this in mind, the Association and the respective host governments used coercion to push them out of their societies-for example, they imposed hut or poll tax on every adult male and in some cases they also expropriated land from them. With time as networks of individuals coming from the same regions grew, migration to South Africa became self-driving. By 1974, labour migrants in South Africa had peaked at a cumulative figure of 400,000 (Griffiths, 1987). It is these foreign nationals that created an initial migration network in South Africa.

Second, the struggle against colonial and then minority rule, which ended in 1994, sparked a wave of emigrations that created thousands of South African refugees (Kliot, 1987). Politically independent neighbouring countries - Angola, Botswana, Lesotho, Mozambique, Swaziland, Tanzania, Zambia, and Zimbabwe - were more than willing to host freedom fighters - more prominently, the African National Congress (ANC), Black Consciousness Movement (BCM), Pan Africanist Congress (PAC), and the United Democratic Front (UDF) - and ordinary South Africans fleeing hostilities due to countermeasures enacted by the colonial and the minority-rule governments to stop movements that advocated for majority-rule. These emigrations peaked between 1960s through to the 1990s, especially after the 1976 student uprising in Soweto (Kliot, 1987). More specifically, Suttner (2003) has described how most members of the African National Congress (ANC) military and security wing left the country when the party was banned by the Apartheid Government in 1961. At first, most ANC members would be out of the country for months before coming back to train others. However, with the top leadership arrested, many exiles ${ }^{23}$ had to camp out of the country for long periods until the party was unbanned in 1990. Further, Suttner (2003) points out that life in exile was extremely difficult for several reasons - such as leaving loved ones behind, crossing hostile regions, as well as facing arrest and interrogation. Therefore, the exiles sought help from the locals who in some cases risked their lives to provide for and protect the comrades. As a result, allegiances ${ }^{24}$ between South Africans and non-South Africans grew and further strengthened migration networks created by the Witwatersrand Native Labour Association (WENELA) forced labour immigration.

Third, the South African Government's deliberate policy to encourage immigration of skilled workers to fill the scarce-skills sectors (Kabwe-Segatti \& Landau, 2008) ${ }^{25}$ has attracted skilled economic immigrants since the late 1980s - with most of them coming from the Southern African Development Community (SADC). Brain draining its neighbouring countries only started to tap off in the mid-1990s - after the Aliens Control Act (ACA) of 1991 meant to control, if not prevent, immigration became effective (Crush \& Williams, 2005). ${ }^{26}$ These

23 The exact number of African National Congress (ANC) comrades who were in exile remains unknown.

24 It is believed that some comrades still travel and visit families they lived with during their exile days. It is also possible that some comrades have facilitated for the non-South African families they lived with to come and stay in South Africa.

25 The South African Department of Labour's description and list of scarce skills is posted and constantly updated on their website: https:/www.labour.gov.za/downloads/documents/useful-documents/skillsdevelopment-act/Scarce\%20skills\%20pamphlet_pamphlet.pdf

26 Crush \& Williams (2005: 7) have argued that even if the post-apartheid Immigration Act was designed to facilitate immigration of skilled personnel, “ ... the more general immigration policy of the post-apartheid government ... [is] ... restrictive and anti-immigrationist ... [to allow for] ... nation-building, job protection for South Africans, and rampant intolerance of outsiders”. 
immigrants might seem the group that formed a network of professionals and, therefore, were not exactly the kind that would spark illegal immigration. To the contrary, the strong extended family arrangements of Africans meant that these individuals had the propensity to attract a family member or a friend that fits the description of an illegal immigrant in South Africa.

Fourth, since signing almost all international treaties on hosting refugees and asylum seekers, South Africa has received political and economic refugees from countries affected by postindependence civil conflicts and misplaced economic policies (Kabwe-Segatti, 2008) - such as Angola, Eritrea, Mozambique, Burundi, Rwanda, Somalia, the Sudan, and Zimbabwe. Although refugees and asylum seekers started arriving during the apartheid regime, their immigration became more pronounced after 1994. According to Kabwe-Segatti (2008: 57), during the 1980s, “... South Africa might have hosted ... over 300000 Mozambican refugees" fleeing war in their country. This massive inflow has only been surpassed by that of Zimbabweans whose "... acknowledgement as refugees is [still] problematic ..." (KabweSegatti, 2008: 63). Further, a year after ushering in the African National Congress, the Government relaxed-that is, amended Section 55 of the 1991 Aliens Control Amendment Act-several immigration measures "... as evidence of South African good will within the wider framework of its incorporation into the South African Development Community ..." (Kabwe-Segatti, 2008: 97). Relaxing immigration measures implied free movements within the Southern African region (Vigneswaran, 2008). There is also evidence that some South African cities have incorporated skilled refugees and asylum seekers into their development outlook and networks (Landau \& Singh, 2008).

Further, like the United States of America - see for example, Sarabia (2012) - the South African Government has provided two major amnesties and are planning another one. First, between 1997 and 2000, the Cabinet offered permanent residence to undocumented Mozambicans who entered South Africa during the 1980 civil war as well as to citizens of Southern African Development Community (SADC) who entered illegally before 1990 (Klotz, 1997; Crush \& Williams, 2005). Second, in 2008, the Government suspended the deportation of Zimbabwean illegal immigrants and legalised their stay in South Africa (Department of National Treasury, 2012). This dispensation reduced deportations from about one quarter of a million per year to less than a hundred thousand annually. Surprisingly, the Department of Home Affairs is not aiming to attain this level of deportations anytime soon because they only plan to deport up to eighty-five thousand illegal immigrants by 2015. Lastly, they are also intending to extend the amnesty they offered to the Zimbabweans to other SADC nationals (Department of National Treasury, 2011).

\section{Exaplanatory frameworks for international movements}

Several textbooks, reports, and journal articles - for example, Massey and others (1993), Thieme (2006) as well as de Haas (2008) - have summarised several migration frameworks that we can use to explain the South African migration streams and the conditions under which they have occurred. Some frameworks explain how migration starts while others explain the conditions under which migration perpetuates (Thieme, 2006). Further, like in most social sciences, demographers have agreed that there is no single framework that can explain migration comprehensively because the reasons why human beings initiate and continue to migrate are multifaceted and intertwined. Besides, the explanatory power of some frameworks is only effective at a particular threshold of a migratory flow and hence their importance varies with time as well as economic and social development. Therefore, to 
explain the South African migration history we suggest invoking all relevant strands of different migration explanatory frameworks. Here, we restrict our discussion to those that are relevant.

One framework that stands out is the "pull and push" theory of migration proposed by Lee (1966). Solomon (2003) has argued that although some scholars - for example, de Haas $(2008,2011)$ - have questioned the explanatory power of this framework, because it is descriptive rather than analytical, it does explain that the gravity of illegal immigration into South Africa is due to push rather than pull factors. Pull factors are attributes that attract people to move to societies pulling them while push factors are attributes that force people to leave their current societies to elsewhere. The third migration stream - immigration into South Africa due to shortage of skilled workers - is the only immigration explained by pull factors. South Africa has an economic and social environment that challenges and rewards skilled and professional personnel. Most, not all, of these immigrants qualify for and have legal documentation that allows them entry and stay in South Africa (Gebrewold, 2007). These individuals usually have an option to go back home or another country if their stay in South Africa does not materialise - an aspect that the decision theory of migration explains in more detail (Beshers, 1967; Sell \& Dejong, 1978).

The remaining three streams - including emigration due to the struggle against minority rule-are all explained by push factors. The Witwatersrand Native Labour Association (WENELA) created push conditions to get labour in neighbouring countries to migrate to South Africa. Refugees and asylum seekers come to South Africa to escape the political and economic wrath of their countries. Further, although not as directly, Solomon (2003) has argued with examples, that most illegal immigrants find themselves in South Africa because the economic and social setup of their respective countries pushes them out. They are more comfortable being in South Africa illegally than in their countries legally because they are escaping the harsh realities of life in their home countries. Inferring from Zolberg (2006: 239), immigration, both legal and illegal, is likely to continue because the “... gap in economic conditions ... [between South Africa and its neighbours] ... is unlikely to be narrowed in the foreseeable future, [therefore] rational human beings will continue ... [coming to South Africa] ... to seek to improve their condition ... even at a high cost".

Further, the pull and push migration explanatory framework nests other frameworks. For example, the world systems theory explains the economic and social position of South Africa relative to its neighbours. The world market structure has developed and expanded unequally among countries leaving some countries and regions more wealthier than others (Wallerstein, 1974). Similarly, by positing that migration is driven by pull factors created by labour market segmentation (Piore, 1979), the dual labour market theory does explain the South African legal immigration. It is also probable that pre-colonial migrations have facilitated postcolonial and post-apartheid migrations within the Southern African region. The unified migration systems theory captures this aspect (Kritz, Lim \& Zlotnik, 1992) by pointing out that migrations mainly occur between regions connected historically, culturally, politically, and economically. At an individual level, the decision theory of migration maintains that people move because individuals want to maximise their benefit (Beshers, 1967).

Lastly and more importantly, the migration networks framework posits that as people migrate and settle in another region, they reduce the next person's financial and emotional cost of migrating (Massey et al., 1993). Therefore, "migration becomes self-perpetuating because migration itself creates the social structure to sustain [itself]" (Massey, 1990: 8). 
Intuitively, every legal or illegal immigrant in South Africa has a potential to facilitate another's immigration into the country. This might explain why correcting this problem by legalising or documenting illegal immigrants actually exacerbates the dilemma. ${ }^{27}$ Therefore, unless managed, migration networks may impede efforts to effectively deter illegal immigration. We should remember that strong migration networks are more likely in Africa because the culture of this continent is still centred on extended family arrangements. Although Solomon (2003) does not rank the core attributes contributing to international movements in Southern Africa, his discussion points to cultural attributes being second after economic attributes - with the others being demographic, socio-political, and environmental. Every ethnic group in this part of Africa has relatives on the other side of the border because of the artificial manner in which the Berlin Conference decided on the African international boundaries. For example, the Ndebele of Zimbabwe as well as the Ngoni of Zambia are historical relatives of the Zulu of South Africa. Similarly, the Barotse people of Western Zambia speak a similar language with the Basotho of Lesotho and South Africa. These historical, cultural, and linguistic links strengthen migration networks across international borders in this region.

In sum, we can attribute the initiation of South African immigration to the pull and largely the push factors. We can also attribute its perpetuation to well-established migratory networks. The political, economic, and social arrangements in sending countries as well as migration social networks in South Africa are rendering enforcement measures ineffective. Kollapen \& Others (1999) have argued that enforcement - that is, capture, detention, and deportation-actually increases the determination of illegal immigrants to return to South Africa. Further, enforcement promotes human rights abuse among law enforcement officials (Polzer, 2010). Regardless, the South African Government has to enact measures to deter illegal immigration effectively - to avert among other problems xenophobic or "Afrophobic" violence. In the next section we discuss findings from interviewing officials that manage illegal immigration to confirm some facts arising from the review thus far.

\section{Research design and methods}

Given the nature of the enquiry, we opted for a qualitative research strategy and a crosssectional design described in Bryman (2012). Further, the study employed a semi-structured interview schedule comprising twelve open-ended questions. We purposively targeted officials in three institutions - the Department of Home Affairs, the South African Police Service, and the South African Human Rights Commission - that have a key role in governing and managing immigration into South Africa (The Constitution of the Republic of South Africa, 1996; Polzer, 2010). Although this was not our target population, we also interviewed two detained illegal immigrants to compare and contrast their views with those of the officials. ${ }^{28}$

Before each interview - that took place between $4^{\text {th }}$ and $24^{\text {th }}$ August 2011 - we informed the respondents about the research and their right of not taking part and not answering questions they are not comfortable with. We assured them that we will never reveal their identities and encouraged them to respond freely. All the six respondents took part in the

27 Though dated, Eisenstadt (1954) points out that in 1948 the newly formed State of Israel faced a similar dilemma when it attempted to integrate or absorb immigrants.

28 We only asked the two detained illegal immigrants the six questions of the twelve on the interview schedule. 
study although some did not answer all the questions. Descriptively, the respondents included a Department of Home Affairs senior official in his mid-forties who has served the Department for 15 years and another officer in his late thirties who has served for 8 years. The other was a colonel in his early fifties who had served the South African Police Service for 22 years. The last official was an experienced 50 year old Commissioner with the South African Human Rights Commission. One of the two detained illegal immigrants was a 34 years old male who had been in detention for 8 months and the other was a 32-year old female who had been in detention for three weeks. The latter had been detained twice before for durations lasting four and two months, respectively. ${ }^{29}$

During our visit to Lindela Repatriation Centre, ${ }^{30}$ we also got a general description of an illegal immigrant in South Africa. Most illegal immigrants are physically fit young males of working age (20-40). This is probably because as the South African Police Service official had remarked, "illegal immigration is risky business and only physically fit males take on such a risk". However, the detained female illegal immigrant observes that the proportion of "female illegal immigrants [is on the increase] because we [females] also have to strive to survive". Because of proximity, most illegal immigrants come from neighbouring countries other than Namibia and Botswana. ${ }^{31}$ However, neither the officials nor the detained immigrants could pinpoint countries that send the most illegal immigrants into South Africa.

After the interviews, we transcribed the responses and analysed the transcripts independently for face and content validity as suggested by Struwig \& Stead (2001). Thereafter, we compared our findings for common themes, namely, "what initiates migrations in contemporary Southern African countries", "why is South Africa the ideal choice of destination for illegal immigrants", as well as "what perpetuates illegal immigration into South Africa". A major limitation of this study is the few interviews conducted due to accessibility and resource constraints. However, we supplemented these interviews with a detailed literature review of academic material and official reports. After reviewing other past studies that have used a similar approach but with more resources - for example, Solomon (2003) - we observe that they also generated similar findings.

\section{Findings and discussion}

Official respondents attribute immigration into South Africa to favourable economic conditions that enable individuals to create wealth-an observation that resonates with the dual labour market theory that suggests that migration is driven by pull factors created by labour market segmentation (Piore, 1979). Such immigrants are usually not convinced that their governments are creating conditions that favour economic growth and social development. However, as the Human Rights Commissioner remarked, "this band of

29 This is almost 1 year 2 months at an average cost of between ZAR36 ; 500 (Mataboge, 2013) and ZAR69 ; 000 per year - The latter estimate came from a senior official of a Cape Town-based Judicial Inspectorate of Prisons (Editor, 2008).

30 Since illegal immigrants should not be detained in ordinary prison facilities, the South African Department of Home Affairs holds them at this facility.

31 Diego Iturralde, the Chief Director of Demographic Analysis at Statistics South Africa, made a similar description, stating that "the majority [of migrants] tend to be younger people with skills generally not at the level of a professional person. They are mostly male, with a significant proportion being female. They are mostly from African countries and mainly self-supporting entrepreneurial types” (Editor, 2012). 
immigrants come to South Africa voluntarily driven by personal ambitions" - an observation captured by the decision theory of migration (Beshers, 1967) that maintains that people move because individuals want to maximise their benefit. This group is not directly the focus of this paper because these immigrants have resources and qualifications to obtain documents that allow them to remain in South Africa legally. Besides, they are not actually pushed out of their countries but rather they are pulled to South Africa.

Neither the officials nor the detained immigrants could pinpoint the nationality of most illegal immigrants in South Africa. However, because of proximity, most illegal immigrants come from neighbouring countries other than Namibia and Botswana. ${ }^{32}$ The officials as well as the detained illegal migrants state that poverty resulting from economic and social insecurity as well as political and cultural conflict in some extreme cases is what compels them to migrate from their respective countries - an aspect captured by the push component of Lee's (1966) pull and push theory. For example, one of the detained immigrants had this to say, "back home I spent days without seeing ... food and did not know where I could find means to survive". The other states that she would not have migrated to South Africa if she had an alternative - "this is the only way I can support my family back home". ${ }^{33}$ To concur, the South African Police Service official remarked that what else other than starvation would explain why "illegal immigrants enter South Africa without fear of conviction". This finding points to earlier reports and arguments that an unfavourable economic and social landscape of sending countries underlies the South African illegal immigration space (Solomon, 2003; Crush \& Williams, 2005; Tati, 2008). This points to why the former Department of Home Affairs Minister, Dr Mangosuthu Buthelezi, noted that it is almost impossible to effectively avert illegal immigration (Vigneswaran, 2008).

A prominent reason why South Africa is the illegal immigrant's destination of choice is that during the apartheid era their countries hosted many prominent figures that are in government today. More specifically, some immigrants see the political ties that South Africans forged with citizens of their countries when they were in exile as a stamped passport into South Africa. One of the two detained illegal immigrants observes that, "many South Africans were 'home' in my country and benefited from the security that my country offered, so I don't understand how that is forgotten in such a short period". As captured by the unified migration systems theory (Kritz et al., 1992), migrations mainly occur between regions connected historically, culturally, politically, and economically. This probably explains why despite doing well in the region, illegal immigrants are not as prominent in Botswana and Namibia (Campbell, 2007).

Lastly and more importantly, it is the deep-rooted migration networks that perpetuate illegal immigration into South Africa. The two detained illegal immigrants observe, "that once in South Africa, we [immigrants from a particular country] live in proximity with each other. We are in touch with our families back home and support them with monies we earn here."

32 Diego Iturralde, the Chief Director of Demographic Analysis at Statistics South Africa, made a similar description, stating that "the majority [of migrants] tend to be younger people with skills generally not at the level of a professional person. They are mostly male, with a significant proportion being female. They are mostly from African countries and mainly self-supporting entrepreneurial types" (Editor, 2012b).

33 This is almost what Yusuf Roble, a Cape Town Immigrant, is reported to have said "I'm told there are many criminals in South Africa, but I will endure them. It is better than being killed by insurgents in Mogadishu" (Isilow, n.d.). 
Further, they state that "when our earnings here [in South Africa] are inadequate to maintain our 'home' (that is, households in their respective countries), we invite our partners and children to our 'new found home' and find them jobs as well". Both these observations are captured in the migration networks framework (Massey, 1990; Massey et al., 1993) that posit that migration becomes self-perpetuating when the cost of moving is reduced by the previous migrants.

\section{Conclusion and recommendations}

This article set out to explain and then interpret why illegal immigrants make South Africa their ideal choice of destination. To do this, the research reviewed the migration history of South Africa to understand its context and extent. Thereafter, we reviewed the established explanatory frameworks to place the immigration history of South Africa in a theoretical perspective. Lastly, we interviewed officials managing illegal immigration to confirm and understand issues arising from literature. In conclusion, we should point out that distinguishing between legal and illegal immigrants in South Africa is important. ${ }^{34}$ The former are mostly white-collar individuals pulled to South Africa to advance their education and career. However, the latter are mostly individuals in non-white-collar occupations pushed out of their respective countries to find means of subsistence in South Africa's construction, service, and commercial farming industries (Crush \& Williams, 2005) as well as small informal enterprises. The pressure to come and remain in South Africa illegally is so great that they hardly mind the consequences. It is likely that the South African Police Service official made the "starvation remark" having witnessed the despair illegal immigrants present when arrested.

The reviews and interviews show that several features define the South African illegal immigration landscape. Largely, we establish that push factors and well-established migratory networks explain contemporary illegal immigration into South Africa. From the work of Polzer (2003), Suttner (2003), Kanyenze (2004), Maharaj (2004), as well as Crush \& Williams (2005) - we conclude that foreign non-skilled labour recruitment, the South African freedom fighters exile programme, immigration of skilled professionals, and massive hosting of refugees and asylum seekers sparked notable immigration. To this, we should add the amnesties the current South African Government has offered to some illegal immigrants.

Further - as suggested by migration networks and cumulative causation frameworks (Massey, 1990) - illegal immigration into South Africa has since become stable and acquired a structure due to strong extended family arrangements of most Africans. ${ }^{35}$ Sociologists have shown that it is strong kinship networks that generate further immigration because they cut the movement and emotional cost of the next migrant (Zolberg, 2006). Similarly, most studies - for example, del Rey Poveda (2007) — have found that international migration is mostly available to families that have the means to migrate. This means, due to established international migratory networks, illegal immigration into South Africa will

34 On this front, there is a need to determine an accurate estimate of illegal immigrants in South Africa. We can use Polzer's (2010) approach or derive an estimate based on the number of legal immigrants. The latter, needs a theory that links legal to illegal immigrants to calculate the proportion of illegal immigrants per legal immigrant. This might give us a working figure at national level which unfortunately may not be helpful at subnational level. 
continue even after there is no push in sending countries and probably no pull in South Africa. This is why when the earnings of immigrants cannot maintain two households (here and their country of citizenship), they do not return to their countries-instead, they invite their family members to South Africa and find them employment.

In sum, while the effects of illegal immigration are within South Africa, the causes of the problem are largely outside its borders. Therefore, to avert illegal immigration, the South African Government needs interventions beyond conventional arrangements. We, recommend a "four-legged" stool, ${ }^{36}$ that is, [1] to commit to serious and effective enforcement so that the Government can [2] firmly but fairly deal with illegal immigrants who are already in South Africa and [3] manage family networks of illegal (and legal) immigrants residing in South Africa rather than legalise or document illegal immigrants. While these humane interventions are welcome, the Department of Home Affairs should control for the ripple effects of family networks - that is, as soon as they legalise an illegal immigrant, she or he attracts another immigrant, illegal or legal. Therefore, as a counter, the Government should control, if not cut, migration networks within and outside South Africa. Lastly and more importantly [4], to deter potential illegal immigrants from coming to South Africa through encouraging, rewarding, and protecting South African private entrepreneurs that provide employment and training to unemployed low-skilled individuals residing in countries with the most illegal immigrants in South Africa. The last stool implies employing initiatives such as the Expanded Public Works Programme (EPWP) to encourage, reward, and protect South African private entrepreneurs that create employment outside the border.

\section{Acknowledgements}

We are grateful to Professor Anthoni van Nieuwkerk and Dr Manamela Matshabaphala for the helpful comments on earlier drafts of this article and more so Dr Mark Orkin and the reviewers for helping us to fine-tune and reconcile our argument and write-up.

\section{References}

Beck, R. B. 2014. The History of South Africa. Santa Barbara: Greenwood.

Beshers, J. M. 1967. Migration. In Beshers, J.M. (ed.), Population Processes in Social Systems. New York: Free Press, pp.131-158.

Bryan, T. 2004. Basic sources of statistics. In Siegel, J.S. \& Swanson, D.A. (eds.), The Methods and Materials of Demography, $2^{\text {nd }}$ edn. London: Elsevier Academic Press, pp.9-42.

Bryman, A. 2012. Research Designs: Social Research Methods, $4^{\text {th }}$ edn. Oxford: Oxford University Press, pp.44-78.

One-leg more than the "three-legged stool" that the United States of America Secretary of the Department of Homeland Security (DHS), Janet Napolitano, has proposed, that is, “ ... a 'threelegged stool" which includes "[1] a commitment to serious and effective enforcement, [2] improved legal flows for families and workers, and [3] a firm but fair way to deal with those who are already here" (Sarabia, 2012: 50). 
Campbell, E.K. 2007. Reflections on illegal immigration in Botswana and South Africa. African Population Studies, 21(2): 23-44.

Cleland, J. 1996. Demographic data collection in less developed countries 1946-1996. Population Studies, 50(3): 433-450.

Crush, J. \& Williams, V. 2005. International Migration and Development: Dynamics and Challenges in South and Southern Africa. Cape Town: South African Migration Project.

de Haas, H. 2008. Migration and development: A theoretical perspective. International Migration Institute Working Paper 9. Oxford: International Migration Institute, University of Oxford.

de Haas, H. 2011. The determinants of international migration: Conceptualising policy, origin and destination effects International Migration Institute Working Paper 39. Oxford: International Migration Institute, University of Oxford.

del Rey Poveda, A. 2007. Determinants and consequences of internal and international migration: The case of rural populations in the south of Veracruz, Mexico. Demographic Research, 16(10): 287-314.

Department of Home Affairs, 2011. Strategic Plan: 2011/12 - 2013/14. Pretoria: Department of Home Affairs.

Department of National Treasury, 2011. Estimates of Public Expenditure 2011: Vote 4 Home Affairs. Pretoria: Department of National Treasury.

Department of National Treasury, 2012. Estimates of Public Expenditure 2012: Vote 4 Home Affairs. Pretoria: Department of National Treasury.

Du Toit, D., Knipe, A., Niekerk, D.V., Waldt, G.V.D. \& Doyle, M.A. 2002. Service Excellence in Governance. Cape Town: Heinemann.

e-Nerws Channel Africa, 2013. Thousands Enter the Country Illegally. http://www.enca.com/south-africa/refuges-south-africa

Editor, 2008. SA prison population among world's highest, IOL Nerws, 26 April 2008. http://www.iol.co.za/news/south-africa/sa-prison-population-among-world-shighest-1.398070\#.UcFxqec3C5I

Editor, 2009. Home affairs in the dark about number of illegal immigrants, Mail $\mathcal{E}^{2}$ Guardian, 13 November 2009. http://mg.co.za/article/2009-11-13-home-affairs-inthe-dark-about-number-of-illegal-immigrants

Editor, 2012. Population dynamics driven by Black Africans, The Fieldworker: Statistics South Africa, p.4.

Eisenstadt, S.N. 1954. The Absorption of Immigrants. London: Routledge and Kegan Paul.

Ellis, S. 2008. South Africa and international migration: the role of skilled labour. In KabweSegatti, A.W. \& Landau, L.B. (eds.), Migration in Postapartheid South Africa: Challenges and Questions to Policy-makers. Paris: Agence Française de Développement, pp.115-133.

Gebrewold, B. 2007. Introduction. In Gebrewold, B. (ed.), Africa and Fortress Europe: Threats and Opportunities. London: Ashgate Publishing Limited.

Griffiths, I. 1987. The traffic in labour. Geographical Magazine, 59: 13-18. 
Hill, K. 1990. Demographic estimation from deficient or defective data. In Fetter, B. (ed.), Demography From Scanty Evidence: Central Africa in the Colonial Era. Colorado: Lynne Rienner Publishers, pp.135-142.

Human Sciences Research Council (HSRC), 2008. Citizenship, Violence and Xenophobia in South Africa: Perceptions from South African Communities. Pretoria: Democracy and Governance Programme, Human Sciences Research Council.

Isike, E.M. 2012. The socio-economic impact of African immigration on urban development in South Africa: The case of Empangeni. OIDA International Journal of Sustainable Development, 3(2): 43-51.

Isilow, H. (n.d.). An illegal immigrant's journey to South Africa. Johannesburg: CII Broadcasting.

Johnson, S., Altbeker, A. \& Bernstein, A. 2010. Skills, growth and borders: Managing migration in South Africa's national interest. Johannesburg: The Centre for Development and Enterprise.

Jones, H.R. 1990. Population Geography, $2^{\text {nd }}$ edn. London: Paul Chapman Publishing Ltd.

Kabwe-Segatti, A.W. 2008. Reforming South African immigration policy in the postapartheid period (1990-2006): what it means and what it takes. In Kabwe-Segatti, A.W. \& Landau, L.B. (eds.), Migration in Postapartheid South Africa: Challenges and Questions to Policy-makers. Paris: Agence Française de Développement, pp.55-113.

Kabwe-Segatti, A.W., \& Landau, L.B. (eds.). 2008. Migration in Postapartheid South Africa: Challenges and Questions to Policy-makers. Paris: Agence Française de Développement.

Kanyenze, G. 2004. African migrant labour situation in Southern Africa. Paper presented at the The International Confederation of Free Trade Unions African Regional Organisation (ICFTU-AFRO) Conference on Migrant Labour held 15-17 March 2004, Nairobi, Kenya.

Kliot, N. 1987. The era of homeless man. Geography, 72(2): 109-121.

Klotz, A. 1997. International relations and migration in Southern Africa. African Security Review, 6(3): 38-45.

Klotz, A. 2012. South Africa as an immigration state. Politikon: South African Journal of Political Studies, 39(2): 189-208.

Kok, P. \& Collinson, M. 2006. Migration and Urbanisation in South Africa. Pretoria: Statistics South Africa.

Kollapen, J., Klaaren, J., Rens, A. \& Schneider, J. 1999. Report into the Arrest and Detention of Suspected Undocumented Migrants. Johannesburg: South African Human Rights Commission.

Kritz, M.M., Lim, L.L. \& Zlotnik, H. (eds.) 1992. International Migration Systems: A Global Approach. Oxford: Clarendon Press.

Landau, L.B. \& Singh, G. 2008. Decentralisation, migration, and development in South Africa's primary cities. In Kabwe-Segatti, A.W. \& Landau, L.B. (eds.), Migration in Postapartheid South Africa: Challenges and Questions to Policy-makers. Paris: Agence Française de Développement, pp.163-211. 
Lebhart, G. 2002. International migration: Hypotheses, theories, and perspectives. Current Demographics, 19: 1-49.

Lee, E.S. 1966. A Theory of Migration. Demography, 3: 47-57.

Maharaj, B. 2004. Immigration to post-apartheid South Africa: Global Migration Perspectives. Stockholm: Global Commission on International Migration, pp.1-27.

Massey, D.S. 1990. Social Structure, Household Strategies, and the Cumulative Causation of Migration. Population Index, 56(1): 3-26.

Massey, D.S., Arango, J., Hugo, G., Kouaouci, A., Pellegrino, A. \& Taylor, E.J. 1993. Theories of international migration: A review and appraisal. Population and Development Review, 19(3): 431-466.

Mataboge, M. 2013. Zimbabwe wants SA to keep its citizens, Mail and Guardian, 17 May 2013. http://mg.co.za/article/2013-05-17-00-zimbabwe-wants-sa-to-keep-itscitizens

Piore, M.J. 1979. Birds of Passage: Migrant Labour and Industrial Societies. Cambridge: Cambridge University Press.

Polzer, T. 2010. Population movements in and to South Africa. Johannesburg: University of the Witwatersrand Forced Migration Studies Programme.

Sarabia, H. 2012. Perpetual Illegality: Results of border enforcement and policies for Mexican undocumented migrants in the United States. Analyses of Social Issues and Public Policy, 12(1): 49-67.

Segatti, A. 2011. Reforming South African immigration policy in the postapartheid period (1990 - 2010). In Segatti, A. \& Landau, L.B. (eds.), Contemporary Migration to South Africa: A Regional Development Issue. Washington: Agence Française de Développement and the World Bank, pp.31-68.

Sell, R.R. \& Dejong, G.F. 1978. Towards a motivational theory of migration decision making Journal of Population, 1(4): 313-334.

Solomon, H. 2003. Of Myths and Migration: Illegal Immigration into South Africa. Pretoria: University of South Africa Press.

South African Municipal Workers' Union, 2012. Attacking and Blaming Foreign Nationals Not the Answer! http://www.samwu.org.za/index.php?option=com_content\&view=article\&id=972:atta cking-and-blaming-foreign-nationals-not-the-answer\&catid=98\&Itemid=93

Statistics South Africa, 2004. Census 2001 Post-enumeration Survey: Results and Methodology. Pretoria: Statistics South Africa.

Statistics South Africa, 2012. Census 2011 Statistical Release. Pretoria: Statistics South Africa.

Struwig, F.W. \& Stead, G.B. 2001. Planning, Designing, and Reporting Research. Cape Town: Pearson Education South Africa.

Suttner, R. 2003. Culture(s) of the African National Congress of South Africa: Imprint of exile experiences. In Melber, H. (ed.), Limits to Liberation in Southern Africa: The Unfinished Business of Democratic Consolidation. Cape Town: Human Sciences Research Council Press, pp.178-199. 
Tati, G. 2008. The Immigration issues in the post-apartheid South Africa: Discourses, policies, and social repercussions. Espace Populations Sociétés, 3: 423-440.

Thieme, S. 2006. Social Networks and Migration: Far West Nepalese Labour Migrants in Delbi. Münster: LIT Publishing House.

Thompson, L.M. 1960. The Unification of South Africa, 1902-1910. London: Oxford University Press.

Vigneswaran, D. 2008. Undocumented migration: risks and myths (1998-2005). In KabweSegatti, A.W. \& Landau, L.B. (eds.), Migration in Postapartheid South Africa: Challenges and Questions to Policy-makers. Paris: Agence Française de Développement, pp.135-162.

Walker, E.A. 1962. A History of South Africa. London: Longman.

Wallerstein, I. 1974. The Modern World-System: Capitalist Agriculture and the Origins of the European World-Economy in the Sixteenth Century. New York: Academic Press.

Wilson, F. 1972. Labour in the South African Gold Mines, 1911-69. Cambridge: Cambridge University Press.

Zolberg, A.R. 2006. Managing a world on the move. Population and Development Revierw, 32(S1): 222-253. 